\title{
Stable isotope ratios and reforestation potential in Acacia koa populations on Hawai'i
}

\author{
S.S. Lawson, C.C. Pike
}

Lawson S. S., Pike C. C. 2017. Stable isotope ratios and reforestation potential in Acacia koa populations on Hawai'i. Ann. For. Res. 60(2): 279-295.

Abstract. Stable carbon and nitrogen isotopes can be influenced by a multitude of factors including elevation, precipitation rate, season, and temperature. This work examined variability in foliar stable carbon $(\delta 13 \mathrm{C})$ and nitrogen $(\delta 15 \mathrm{~N})$ isotope ratios of koa (Acacia koa) across 17 sites on Hawai'i Island, delineated by elevation and precipitation gradients. Sites were identified and grouped with respect to mean annual precipitation (MAP), mean annual temperature (MAT) and position along three elevation transects. Analysis of resultant $\delta 13 \mathrm{C}$ and $\delta 15 \mathrm{~N}$ isotope ratios from multiple individuals across ecoregions indicated certain regions exhibited a correlation between carbon and/or nitrogen content, isotope ratios, precipitation, and elevation however, many comparisons showed no correlation. We used publicly available temperature and moisture data to help eliminate confounding effects by climatic drivers and capture possible points of contention. At sites where the temperature, precipitation, and elevation data were not significantly different, we compared stable isotope information to determine if additional variables might have contributed to a lack of definitive data. Our results identified several areas within the Waiakea Forest Reserve and Volcanoes National Park where, based on isotope analyses, reforestation efforts could be most successfully initiated.

Keywords Acacia koa, elevation, Hawaiian, isotopes, plasticity

Authors. Shaneka S. Lawson (sslawson@fs.fed.us), USDA Forest Service, Northern Research Station, Hardwood Tree Improvement and Regeneration Center (HTIRC), Purdue University, 715 West State Street, West Lafayette, IN USA 47907; Carolyn C. Pike, USDA Forest Service, Northeastern Area State and Private Forestry, Purdue University, 715 West State Street, West Lafayette, IN USA 47907.

Manuscript received June 15, 2017; revised July 7, 2017; accepted July 14, 2017; online first July 21, 2017.

\section{Introduction}

Koa (Acacia koa) is a tree species endemic to all islands within the Hawaiian archipelago but only exists in populations of sufficient size to be called forests on the islands of Hawai'i, 
Kauai, Maui, and Oahu. Koa trees are legumes, a vital representative of tropical forests due to their ability to fix nitrogen. Several examples exist regarding the preference or prevalence of nitrogen-fixing trees on disturbed sites with limited nitrogen, as opposed to undisturbed sites (Roggy et al. 1999, Ometto et al. 2006). This majestic tree is found across a wide range of elevation (300-2200 m) and temperature $\left(11-23{ }^{\circ} \mathrm{C}\right)$ gradients. Important to the timber industry and closely tied to Native Hawaiian culture, koa populations have suffered decline following unchecked free-range cattle grazing, introduction of invasive grasses, as well as other abiotic and biotic threats. Because of the significant timber and ecological value of koa, studies of its natural plasticity and potential for range expansion are needed to help formulate scenarios directed towards halting population decline through assisted restoration of the species.

Recent forest cover data collected across both tropical and alpine indicator species highlighted population shifts in response to environmental variability (Rannow 2013, Juday et al. 2015). Aided by analyses of temperature and precipitation gradients, tropical plant researchers in Hawai'i have also noted subtle shifts in the range of native Hawaiian plant species in response to climate change (Krushelnycky et al. 2013) but this work did not extend to forest tree species. Krushelnycky (2014) noted that a decline in plant numbers would result in increased distances between host plants and altered behavior of insect pollinators. These data highlight the importance of maintaining population sizes and decreased habitat fragmentation on future reproductive success. Nearly a decade ago, Aitken et al. (2008) proposed that tree species capable of a greater degree of adaptation, were most likely to survive future climatic change trees may experience range expansion or contraction depending on inherent plasticity and availability of suitable soils and site conditions in novel locations, versus less plastic species that will exhibit decreased population representation 280 across locations (Ozolincius et al. 2014, Juday et al. 2015).

Temperatures are increasing across many sites on and near the Hawai'i Island chain (Murakami et al. 2013, Safeeq et al. 2013) and tropical forests worldwide (Marcott et al. 2013, Vlam et al. 2014). While these temperature data effectively show overall changes across several sites, the resultant effects on native tree populations have not been thoroughly examined. The effects of changes to temperature and precipitation on tree growth and development may be positive or negative depending on site, morphological and physiological characteristics of the species' (Vitasse et al. 2009, Vitasse et al. 2014, Bussotti \& Pollastrini 2015). On the Mediterranean island of Mallorca, Gulías et al. (2009) reported correlations between meteorological variability and both growth form and environmental adaptation. It was also noted that physiological characteristics can be used in estimations of ecosystem responses. Similar results were found in studies of tropical forest species from Xishuangbanna Botanical Garden in Yunnan, China (Cai et al. 2008).

Stable isotopes have been used for decades in both plant and animal studies to investigate nutrient cycling and environmental compatibility. Carbon isotopes are used in research to provide insight on intrinsic water-use efficiency as well as how efficiently plants photosynthesize. Plants occurring across a wide range of microhabitats, ranging from sloping hills to alluvial valleys, exhibit plasticity in their rooting patterns. At high elevations roots are shallow, compared to valleys with deep soils, and therefore have less access to soil water at the high elevations (Liu et al. 2014). These moisture shortages can effectively be reflected in foliar carbon $\left(\delta^{13} \mathrm{C}\right)$ and nitrogen isotope $\left(\delta^{15} \mathrm{~N}\right)$ data (Casper et al. 2012, Liancourt et al. 2013). Initial research using carbon isotope values allow for general comparative analyses across sites within an area and may not allow for differences in plant micro-distributions, or alterations of population substructure that have 
become more prevalent due to climate change (Peterson \& Fry 1987, Ward et al. 2005).

Isotopes such as $\delta^{13} \mathrm{C}$ and $\delta^{15} \mathrm{~N}$ have been used extensively to understand numerous ecosystem processes. Plants discriminate against the heavier $\delta^{13} \mathrm{C}$ molecules when $\mathrm{CO}^{2}$ is assimilated allowing for calculation of subsequent of $\delta^{13} \mathrm{C}$ to $\delta^{12} \mathrm{C}$ ratios. The expression of this ratio is an indication of environmental factors contributing to the identification of those plants under greater water stress. Detection of carbon isotope ratios differences in stomatal conductance and carboxylation that underscore photosynthetic machinery and plant responses to varied environmental conditions. Also, carbon isotope ratios vary with plant type. For example, C3 plants typically exhibit lower ratios (-33 to $-23 \%$ ) than $\mathrm{C} 4$ plants $(-16$ to $-10 \%$ ) hence, these values can be used to differentiate between the photosynthetic pathways of known and unknown plant species (Lynott et al. 1986, Kohn \& Thiemens 2010, Magdas et al. 2014). Nitrogen isotopes have also been used to describe many phenomena ranging from climate change effects on nutrient cycling to relative density of mycorrhizal fungi in the soil. Craine et al. (2009) conducted a meta-analysis on nitrogen isotopes $\left(\delta^{15} \mathrm{~N}\right)$ from independent studies conducted around the world to examine potential patterns in terrestrial nitrogen cycling.

Carbon isotopes encapsulate cumulative effects of stomatal conductance, $\mathrm{CO}^{2}$ assimilation, and transpiration function during the lifetime of a plant, rather than over the course of a single growing season. Plants discriminate between the heavier $\delta^{13} \mathrm{C}$ and standard $\delta^{12} \mathrm{C}$ molecules at a predictable rate during photosynthesis and $\mathrm{CO}^{2}$ acquisition. Comparisons of the ratio of $\delta^{13} \mathrm{C}$ to $\delta^{12} \mathrm{C}$ in a sample are indicative of how that plant grew over time and whether it had a greater WUE or tolerance to abiotic stress. Links have been made between precipitation, temperature, and overall climate oscillations using data acquired from isotopic studies. The majority of researchers acknowledge that climate change will result in increased temperatures globally. Both carbon and nitrogen isotope readings have been linked to climate and land-use change and are considered excellent tools to help understand the true implications of these environmental shifts.

The use of stable isotope comparisons for tree populations differing in elevation, temperature and moisture gradients have widely been accepted as a means used to determine overall physiological adaptation (Soolanayakanahally et al. 2015, Bell et al. 2017). Fractionation and measurement of stable isotopes such as $\delta^{13} \mathrm{C}$ / $\delta^{12} \mathrm{C}$ and $\delta^{15} \mathrm{~N} / \delta^{14} \mathrm{~N}$ provided reliable means for evaluation of these and numerous additional physiological processes in plants. Use of stable isotopes for determination of water-use efficiency (WUE) (Hansen \& Steig 1993, Ares et al. 2000) and abiotic stress (Hansen et al. 1996, Craven et al. 2010) conditions has been previously reported. Other researchers suggest that, providing no confounding temperature, precipitation, or light data; overall $\delta^{13} \mathrm{C}$ also decreases at higher altitudes (Heitz 1998, Zhu et al. 2010).

Vitousek et al. (1994) and Idol et al. (2007) examined overall koa ecosystem productivity and noted that leaf nutrient concentrations in dry regions may increase, relative to wet areas, in part because of reduced growth in water-limited environments. Generally, $\delta^{13} \mathrm{C}$ discrimination decreases at high altitudes, however, overall moisture can significantly interfere with and effectively reverse this trend ( $\mathrm{Zhu}$ et al. 2010). Recent work by Berry \& Smith (2012) correlated variation in foliar water uptake with elevation and later, to the presence of fog in a cloud forest environment (Berry et al. 2014). The presence of fog, and its influence on stable isotope discrimination, has been reported for Maui (Scholl et al. 2002), but to our knowledge, such reports with respect to fog and its effects on isotopes have not been generated for Hawai'i.

Stable nitrogen ratios have been used to represent nitrogen cycling efficiency within plants following land use and land cover changes (Robinson 2001, Perakis et al. 2015), and has 
been used to both evaluate interspecific competition between tree species (Hagan \& Jose 2011) and differentiate between organic and synthetic nitrogen uptake (Mihailova et al. 2014). Decreases in annual rainfall have been linked to a concomitant increase in foliar $\delta^{15} \mathrm{~N}$ in some tree species. Thus, as both the amount of rainfall and frequency of rainfall events decrease, foliar $\delta^{15} \mathrm{~N}$ would decline (Schulze et al. 1998). Secondly, as $\mathrm{CO}^{2}{ }_{\mathrm{atm}}$ concentrations increase leaf nitrogen concentrations in some tree species may decrease (Breklin et al. 2014, Voelker et al. 2016). In addition, cattle grazing can enhance foliar $\delta^{15} \mathrm{~N}$ values as noted by Hall et al. (2015). Therefore, at sites on the island of Hawai'i subjected to feral cattle grazing, foliar $\delta^{15} \mathrm{~N}$ data is confounded with other effects. In addition to ungulates, fire, inter-tree interactions, and topography effects have also been known to alter $\delta^{15} \mathrm{~N}$ readings (Watzka et al. 2006, Riedel et al. 2013, Perakis et al. 2015), strongly suggesting that past site history is an important consideration when developing planting site recommendations (Farley et al. 2013).

Shifts in nitrogen isotopes have proven useful to evaluate plant uptake patterns for air pollution research and to capture how sulfuric and other gasses affect plant nutrient levels (Cada et al. 2016). The presence of vog (volcanic smog), a corrosive hydrochloric acid produced by the chemical reaction between lava and seawater at several of the sites within Volcanoes National Park (VNP), can influence foliar uptake at those sites and several other sites where fog typically lingers.

This work examined stable carbon and nitrogen isotopes obtained from foliar samples of koa collected at nearly two dozen sites on the island of Hawai'i. The objective of this study was to determine if the leguminous species Acacia koa demonstrated plasticity across several local environmental parameters and to determine which ecoregions were likely to be the most suitable for future small-scale restoration efforts. We used variations in temperature and precipitation along an elevation gradient to 282 document distinctive patterns in foliar isotope signature that can be observed in response to environmental cues.

\section{Materials and methods}

\section{Study sites}

We selected 17 sites for this study of Acacia koa (herein referred to as koa) along an elevation and precipitation gradient on the island of Hawai'i (19० $\left.38^{\prime} \mathrm{N}, 155^{\circ} 33^{\prime} \mathrm{W}\right)$. Sites were located at the Hawai'i Experimental Tropical Forest, Hilo Forest Reserve, Kanakaleonui Bird Corridor, Kipuka Pu'u Huluhulu Native Tree Sanctuary, Laupahoehoe Experimental Forest, Ola'A Forest Reserve, Volcanoes National Park, and Waiakea Forest Reserve. Sites were classified based on elevation $(\leq 750 \mathrm{~m}=$ Low, 750-1500 m = Mid, $\geq 1500 \mathrm{~m}=$ High) and average annual precipitation (MAP) $(\leq$ $150 \mathrm{~cm}=$ Dry, $150-450 \mathrm{~cm}=$ Mesic, $\geq 450 \mathrm{~cm}$ = Wet) (Figure 1, Supporting Information 1). The selected sites were predominantly covered by mature koa trees, with some sites including scattered O'hia (Metrosideros polymorpha) trees present as well.

\section{Climate and meteorological data}

Hawai'i Island is strictly defined as a tropical island with several distinct climate zones centrally (longitudinally) divided by the volcanic peaks of Mauna Kea and Mauna Loa. The southern and western half of the island (leeward) is relatively dry from rain shadowing while the northern and eastern half (windward) experiences frequent heavy precipitation events because of orographic lift. Average annual precipitation on the island varies dramatically from $\leq 25.4 \mathrm{~cm}$ to $254 \mathrm{~cm}$ leeward and $\geq 254 \mathrm{~cm}$ to $1016 \mathrm{~cm}$ windward (Western Regional Climate Center (WRCC), http://www. wrcc.dri.edu/) (Table 1). Hawai'i displays two seasons; summer (Kau) and winter (Hooilo). Summer extends from May to September with 


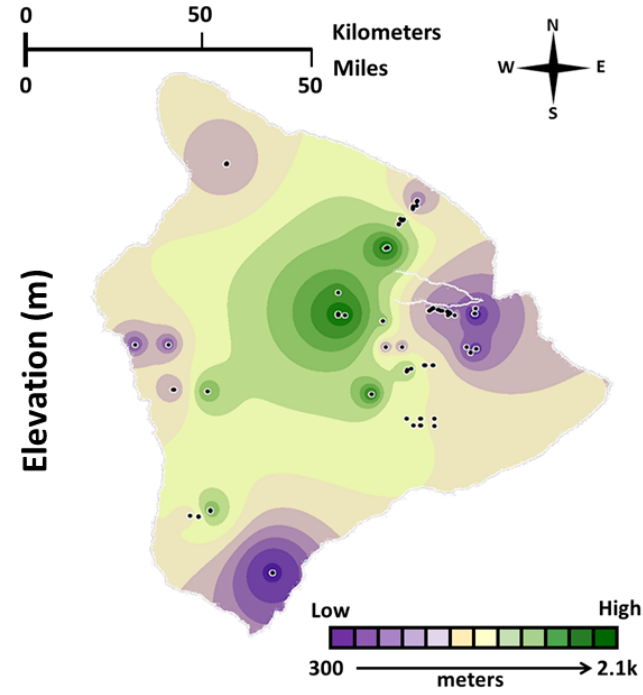

Figure 1 Elevation gradients across Hawai'i Island

an average daytime temperature of $29{ }^{\circ} \mathrm{C}$. Winter extends from October to April with an average daytime temperature of $26^{\circ} \mathrm{C}$. Precipitation accumulates primarily in winter while summer months are typically drier (WRCC). We collected samples during both periods to confirm that no significant differences existed between seasons. Precipitation data were obtained from the Rainfall Atlas of Hawai'i (http://rainfall.geography.Hawai'i.edu/) and Kolivras \& Comrie (2007). Samples were collected in July 2013 and January 2014 as an extreme drought covered most of the state (Supporting Information 2). Comparison of isotope data from samples collected in July to those collected in January indicated no statistically significant differences overall. Therefore, we pooled data across collection dates for final analyses.

\section{Experimental design and sampling}

We attempted to sample trees that were mature and appeared to be naturally-regenerated based on age class distribution and local knowledge. We avoided trees that occurred along forest edges. Trees represented multiple age classes and various sizes: the smallest diameter (mea- sured at breast height, 1.3 meters from ground) sampled was $1.3 \mathrm{~cm}$ with the largest being 182 $\mathrm{cm}$. Thirty samples were $<10 \mathrm{~cm}$, two hundred were $>10$ and $<50 \mathrm{~cm}$ and seventy-six were $>50 \mathrm{~cm}$. The only selection requirement was for the tree to be healthy. We did our best to collect from mature trees, but not sites had a surfeit population of mature individuals. Foliar samples (phyllodes) were collected from the mid-canopy of each tree using a pole pruner to reduce potential variability in isotope data resultant of canopy profile position. Once a grouping of phyllodes were selected, they were immediately stripped from the branch by hand, placed into a pre-labeled bag, and submerged in liquid nitrogen to maintain them for later examination. Foliar carbon and nitrogen isotope ratios were determined for populations of koa within each ecoregion except for the high-wet region as no high-wet locations were identified (Table 1).

\section{Stable isotope analysis}

Phyllodes from each tree collected in Hawai'i were shipped on dry ice to the Plant Tissue Culture and Genomics Laboratory at Purdue University (https://ag.purdue.edu/fnr/Pages/ labtissue.aspx) for further processing. Phyllodes were oven-dried in metal pans at $65^{\circ} \mathrm{C}$ for 3 days, and subsequently ground into a fine powder with mortar and pestle (Corning $\left.{ }^{\circledR}\right)$ before being transferred into $2 \mathrm{ml}$ Eppendorf tubes (Dot Scientific, Inc.). Each tube was individually numbered and shipped in bulk to the Boise State Stable Isotopes Laboratory (http://earth.boisestate.edu/stable-isotopes/) for foliar nutrient (percent carbon, $\% \mathrm{C}$; percent nitrogen, $\% \mathrm{~N}$ ) and stable isotope analysis (carbon isotope discrimination, $\delta^{13} \mathrm{C}$; nitrogen isotope discrimination, $\delta^{15} \mathrm{~N}$ ). Measurements of $\% \mathrm{C}$ and $\% \mathrm{~N}$ were generated using a continuous flow isotope ratioing mass spectrometer (C-FIRMS). Values for isotope discrimination are reported per the PDB standard (Schulze et al. 1996). National Institutes of Standards and 
Table 1 Basic environmental data for the selected sites

\begin{tabular}{lllllrl}
\hline Site ID & $\begin{array}{l}\text { Primary } \\
\text { Climate }\end{array}$ & $\begin{array}{l}\mathrm{MAP}^{1} \\
(\mathrm{~mm})\end{array}$ & $\begin{array}{l}\mathrm{MAE}^{2} \\
(\mathrm{~mm})\end{array}$ & $\begin{array}{l}\mathrm{MAT}^{3} \\
\left({ }^{\circ} \mathrm{C}\right)\end{array}$ & \multicolumn{1}{c}{$\begin{array}{l}\text { Tree Height } \\
(\mathrm{cm})\end{array}$} & Other observed microclimates \\
\hline AKO & Low-mesic & 4840.83 & 765.05 & 20.26 & $1815.0 \pm 537.6$ & \\
BIR & High-dry & 1416.35 & 584.91 & 9.94 & $975.8 \pm 410.0$ & \\
FLM & Low-wet & 5522.63 & 946.57 & 18.49 & $868.0 \pm 515.7$ & \\
HON* & Mid-dry & 878.09 & 502.94 & 14.57 & $1080.8 \pm 564.4$ & High-dry \\
KEK$^{*}$ & Mid-dry & 1146.84 & 537.68 & 15.51 & $1409.3 \pm 393.1$ & High-dry \\
LAU* & Mid-mesic & 3471.78 & 906.22 & 15.29 & $2030.0 \pm 954.0$ & Low-mesic, High-mesic \\
MAU & High-dry & 1663.30 & 644.99 & 10.48 & $606.0 \pm 232.0$ & \\
MIL & Low-wet & 5725.87 & 671.27 & 17.72 & $1349.3 \pm 375.9$ & \\
PHH & High-dry & 1026.56 & 570.13 & 10.57 & $841.0 \pm 226.4$ & \\
SAD* & Mid-wet & 5815.47 & 662.26 & 16.44 & $1259.3 \pm 785.7$ & Low-wet, High-dry \\
SBR* & High-mesic & 4208.43 & 777.79 & 15.55 & $1223.3 \pm 422.6$ & Low-wet, Mid-wet, Mid-mesic \\
VNP-A & Mid-mesic & 2046.62 & 651.74 & 16.40 & $1581.4 \pm 645.6$ & \\
VNP-B & Mid-mesic & 2046.62 & 651.74 & 16.40 & $880.5 \pm 571.5$ & \\
VNP-C & Mid-mesic & 2905.12 & 795.43 & 15.93 & $1031.8 \pm 517.6$ & \\
VNP-D & Mid-mesic & 1785.60 & 714.17 & 15.94 & $1352.5 \pm 599.5$ & \\
VNP-E & Mid-mesic & 2677.02 & 800.69 & 15.62 & $1441.7 \pm 379.6$ & \\
WAI & Low-dry & 1329.09 & 647.83 & 20.76 & $804.0 \pm 188.9$ & \\
\hline
\end{tabular}

Note. Abbreviations: ${ }^{1}$ Mean annual precipitation, ${ }^{2}$ Mean annual evapotranspiration, ${ }^{3}$ Mean annual temperature, *We observed multiple microclimate types at these site designations.

Technology (NIST) peach protocols were used for normalization and machine accuracy was assured when baseline standards for each individual were analyzed in quadruplicate. Acetanilide was used as a control for the calculations of carbon and nitrogen percentages while carbon and nitrogen isotope values were calculated with a two-point normalization using both acetanilide and keratin. Time-integrated water-use efficiencies were represented using $\delta^{13} \mathrm{C}$ data. All $\delta^{13} \mathrm{C}$ values were calculated using the formula $\delta^{13} \mathrm{C}\left[\left({ }^{13} \mathrm{C}:{ }^{12} \mathrm{C}\right.\right.$ leaf $)$ relative to $\left.\left({ }^{13} \mathrm{C}:{ }^{12} \mathrm{CO}_{2 \mathrm{~atm}}\right)\right]$ and represented by $\delta^{13} \mathrm{C}(\%)$ while $\delta^{15} \mathrm{~N}$ values were determined where $\delta^{15} \mathrm{~N}$ $\left[\left({ }^{15} \mathrm{~N}:{ }^{14} \mathrm{~N}\right.\right.$ leaf $)$ relative to $\left.\left({ }^{15} \mathrm{~N}:{ }^{14} \mathrm{~N}_{\mathrm{atm}}\right)\right]$ represented by $\delta^{15} \mathrm{~N}(\%)$.

\section{Statistical analysis}

All variables $\left(\% \mathrm{C}, \delta^{13} \mathrm{C}, \% \mathrm{~N}, \delta^{15} \mathrm{~N}\right.$, and tree height) were examined for distribution and homoscaedasticity. All traits exhibited stable variances but were skewed at the tails. Firstly, we used Pearson correlation to compare relationships for variables $\% \mathrm{C}$, Delta $\mathrm{C}, \% \mathrm{~N}$, and Delta $\mathrm{N}$ to observe patterns with temperature and precipitation and relationships among variables (Tables 2-3). Next, we used linear mixed models (SAS, Proc Mixed) to compare three levels of elevation (high, med, low) and three levels of precipitation (wet, mesic, dry) and their interactions as fixed variables, and random effects of site, and residual error for the five variables of interest. Because of significant interactions for elevation, we compared moisture (wet, mesic, dry) at each of three elevations: low (530 meters), median (1240) and high elevations $(2640 \mathrm{~m})$ using Tukey's test at $\mathrm{p}<0.05$. All analyses were performed using SAS statistical software v 9.4 (2012 SAS Institute Inc., Cary NC). 

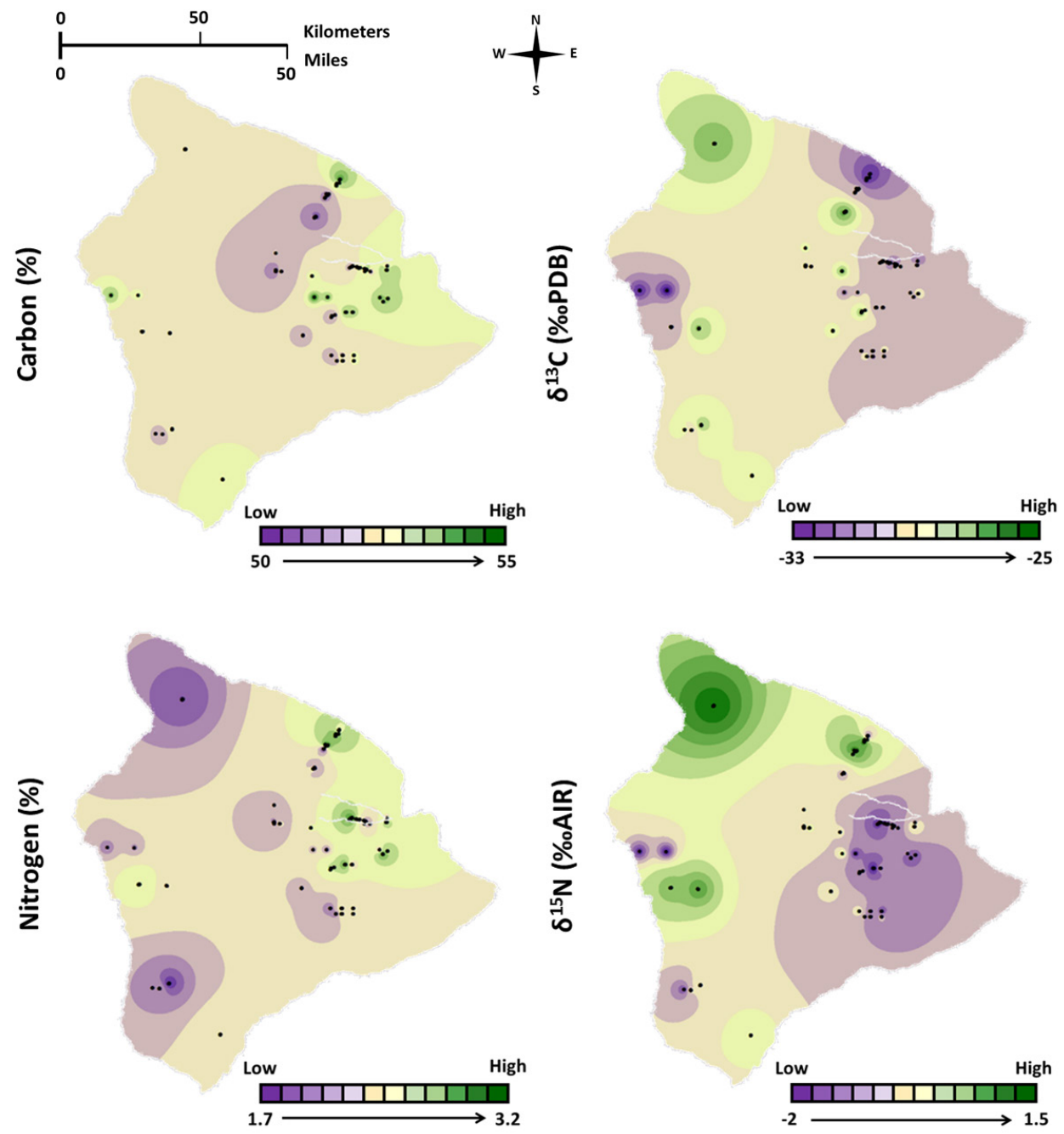

Figure 2 Map of individual trees sampled. Foliar $\delta 13 \mathrm{C}$ and $\delta 15 \mathrm{~N}$ data with $\mathrm{C}$ and $\mathrm{N}$ concentrations at study sites around the island

\section{Results}

Percent natural abundance for both carbon and nitrogen were higher on the windward than leeward side of the island (Figure 2). Both \%C and $\% \mathrm{~N}$ were significantly and positively correlated with mean temperature in July (MTY), mean precipitation in July (MPY), mean annual temperature (MAT) and mean annual precipitation (MAP) (Table 2). Percent $\delta^{13} \mathrm{C}$ was significantly and negatively correlated with
MTY, MPY, MAT, and MAP (Table 2). Percent $\delta^{15} \mathrm{~N}$ was negatively correlated with MPY and MAP but not with MAT.

Trees were significantly taller at mesic than wet sites, with an average height of $12.17 \mathrm{~m}$ and $8.27 \mathrm{~m}$, respectively. Tree heights were intermediate at dry sites, relative to mesic and wet $(10.15 \mathrm{~m})$. Across traits, tree height was negatively correlated with $\delta^{13} \mathrm{C}$, weakly positive with $\% \mathrm{~N}$, but was not significantly correlated with $\delta^{15} \mathrm{~N}$. Percent $\mathrm{C}$ was significantly 
Table 2 Correlation values for basic climate and isotope data

\begin{tabular}{lllll}
\hline Climate Factors & $\% \mathrm{C}$ & $\delta^{13} \mathrm{C}(\% \mathrm{PDB})$ & $\% \mathrm{~N}$ & $\delta^{15} \mathrm{~N}(\% \mathrm{AIR})$ \\
\hline Mean Temp January $\left(\mathrm{MTJ},{ }^{\circ} \mathrm{C}\right)$ & 0.01 & 0.05 & 0.33 & 0.01 \\
Mean Precipitation January (MPJ, mm) & 0.01 & 0.01 & 0.05 & $\mathbf{0 . 1 3}$ \\
Mean Temp July (MTY, $\left.{ }^{\circ} \mathrm{C}\right)$ & $\mathbf{0 . 5 0}$ & 0.32 & $\mathbf{0 . 1 3}$ & 0.01 \\
Mean Precipitation July (MPY, mm) & $\mathbf{0 . 5 3}$ & 0.30 & $\mathbf{0 . 1 9}$ & 0.20 \\
Mean Annual Temperature (MAT, $\left.{ }^{\circ} \mathrm{C}\right)$ & $\mathbf{0 . 5 8}$ & 0.35 & $\mathbf{0 . 1 5}$ & 0.01 \\
Mean Annual Precipitation (MAP, mm) & $\mathbf{0 . 5 4}$ & 0.36 & $\mathbf{0 . 2 0}$ & 0.23 \\
\hline
\end{tabular}

Note. The values in bold indicate positive correlation, while italics, negative correlation.

Table 3 Pearson correlation coefficients with p-values for traits of interest

\begin{tabular}{cllllcc}
\hline & $\% \mathrm{C}$ & $\delta^{13} \mathrm{C}$ & $\delta^{15} \mathrm{~N}$ & $\% \mathrm{~N}$ & $\mathrm{Ht}(\mathrm{m})$ & $\mathrm{DBH}^{2}(\mathrm{~cm})$ \\
\hline \multirow{2}{*}{$\% \mathrm{C}$} & 1 & -0.290 & -0.170 & -0.0200 & 0.1800 & 0.0600 \\
& & $<.0001$ & $\mathbf{0 . 0 0 1}$ & 0.6900 & $\mathbf{0 . 0 1 0 0}$ & 0.2700 \\
$\delta^{13} \mathrm{C}$ & 1 & 0.300 & 0.1600 & -0.3800 & -0.0900 \\
& & & $<.0001$ & $\mathbf{0 . 0 0 1 6}$ & $<.0001$ & 0.0800 \\
$\delta^{15} \mathrm{~N}$ & & & 0.0900 & 0.0140 & 0.0100 \\
& & & 0.0800 & 0.7900 & 0.8200 \\
$\% \mathrm{~N}$ & & & 1 & 0.1300 & -0.0000 \\
& & & & $\mathbf{0 . 0 1 0 6}$ & 0.9776 \\
$\mathrm{Ht}^{1}(\mathrm{~m})$ & & & & 1 & 0.5200 \\
& & & & & $<.0001$ \\
\hline
\end{tabular}

Note. Abbreviations. ${ }^{1}$ Height, ${ }^{2}$ Diameter at breast height. The values in bold are statistically significant.

Table 4 ANOVA p-values testing significance of main effects (moisture, elevation) and interactions. Three levels of moisture (wet, mesic, dry) and elevation effects (high, med, low) were tested

\begin{tabular}{lccc}
\hline Trait & Moisture (3) & Elevation $(3)$ & M x E (9) \\
\hline$[\mathrm{C}] \%$ & $\mathrm{NS}$ & $<\mathbf{0 . 0 0 1}$ & $\mathrm{NS}$ \\
$\delta^{13} \mathrm{C}(\%$ PDB $)$ & $<\mathbf{0 . 0 5}$ & $<\mathbf{0 . 0 1}$ & $<\mathbf{0 . 0 1}$ \\
{$[\mathrm{N}] \%$} & $\mathrm{NS}$ & $\mathrm{NS}$ & $\mathrm{NS}$ \\
$\delta^{15} \mathrm{~N}(\%$ AIR) & $<\mathbf{0 . 0 1}$ & $<\mathbf{0 . 0 1}$ & $<\mathbf{0 . 0 1}$ \\
Tree height & $<\mathbf{0 . 0 5}$ & $<\mathbf{0 . 0 5}$ & $\mathrm{NS}$ \\
\hline
\end{tabular}

Note. The values in bold are statistically significant.

Table 5 Results of Tukey's test at a low $(530 \mathrm{~m})$, median $(1240 \mathrm{~m})$ and high elevations (2064 m). Similar letters within each elevation indicate similar values of $\delta 13 \mathrm{C}$ or $\delta 15 N$. Height was back-transformed into units of measure (meters)

\begin{tabular}{lllll}
\hline Elevation & Moisture & $\delta^{13} \mathrm{C}$ & $\delta^{15} \mathrm{~N}$ & Height \\
\hline \multirow{3}{*}{$530 \mathrm{~m}$} & wet & $-30.3^{\mathrm{a}}$ & $-0.77^{\mathrm{a}}$ & $10.1^{\mathrm{b}}$ \\
\cline { 2 - 5 } & mesic & $-31.9^{\mathrm{a}}$ & $-2.23^{\mathrm{b}}$ & $14.9^{\mathrm{a}}$ \\
\cline { 2 - 5 } & dry & $-30.3^{\mathrm{a}}$ & $-0.79^{\mathrm{ab}}$ & $12.4^{\mathrm{ab}}$ \\
\hline \multirow{3}{*}{$1240 \mathrm{~m}$} & wet & $-30.8^{\mathrm{b}}$ & $-0.68^{\mathrm{a}}$ & $8.2^{\mathrm{b}}$ \\
\cline { 2 - 5 } & mesic & $-29.9^{\mathrm{ab}}$ & $-1.01^{\mathrm{a}}$ & $12.1^{\mathrm{a}}$ \\
\cline { 2 - 5 } & dry & $-28.9^{\mathrm{a}}$ & $-0.35^{\mathrm{a}}$ & $10.1^{\mathrm{ab}}$ \\
\hline \multirow{2}{*}{$2064 \mathrm{~m}$} & wet & $-31.1^{\mathrm{b}}$ & $-0.59^{\mathrm{a}}$ & $6.4^{\mathrm{b}}$ \\
\cline { 2 - 5 } & mesic & $-27.6^{\mathrm{a}}$ & $0.39^{\mathrm{a}}$ & $9.5^{\mathrm{a}}$ \\
\cline { 2 - 4 } & dry & $-27.3^{\mathrm{a}}$ & $0.16^{\mathrm{a}}$ & $7.9^{\mathrm{ab}}$ \\
\hline
\end{tabular}


and positively correlated with $\% \mathrm{~N}$ but not with $\delta^{15} \mathrm{~N}$ (Table 3).

Tree heights, $\delta^{13} \mathrm{C}$, and $\delta^{15} \mathrm{~N}$ differed with respect to moisture and elevation and we observed a significant moisture $\mathrm{x}$ elevation interaction for both $\delta^{13} \mathrm{C}$ and $\delta^{15} \mathrm{~N}$ (Table 4). We examined this interaction by comparing differences in means among moisture types at low $(530 \mathrm{~m})$, median $(1240 \mathrm{~m})$ and high elevations $(2064 \mathrm{~m})$. Differences among moisture classes for $\delta^{13} \mathrm{C}$ were significant only at mid and high elevations (Table 5). The slopes using regression of $\delta^{13} \mathrm{C}$ with elevation for dry $\left(\mathrm{R}^{2}=0.04 ; \mathrm{y}=0.0005 \mathrm{x}-29.528\right)$, mesic $\left(\mathrm{R}^{2}\right.$ $=0.21 ; \mathrm{y}=0.0035 \mathrm{x}-34.459)$, and wet $\left(\mathrm{R}^{2}=\right.$ $0.23 ; y=0.0017 x-31.485)$ regions were just significant $(\mathrm{p}<0.05)$. Thus, high elevation trees on wet sites exhibited relatively lower rates of stomatal conductance, or more negative values of $\delta^{13} \mathrm{C}$, than their counterparts on dry or mesic sites. For $\delta^{15} \mathrm{~N}$ by elevation, slopes were also significantly different among dry $\left(\mathrm{R}^{2}=0.03\right.$; $\mathrm{y}=-0.0002 \mathrm{x}+0.0161)$, mesic $\left(\mathrm{R}^{2}=0.06 ; \mathrm{y}\right.$ $=0.0015 \mathrm{x}-2.3609)$, and wet $\left(\mathrm{R}^{2}=0.03 ; \mathrm{y}=\right.$ $-0.0003 \mathrm{x}-1.0286)$ regions, showing a general decrease in $\delta^{15} \mathrm{~N}$ with elevation for dry and wet regions and an increase for trees in mesic regions from low to high elevations (Figure 3 , Table 5). At low elevations, wet and mesic sites exhibited significantly different levels of $\delta^{15} \mathrm{~N}$ isotopes (Table 5), but differences were not detectable at mid (1240 meters) or high (2064 meters) elevations (Table 5).

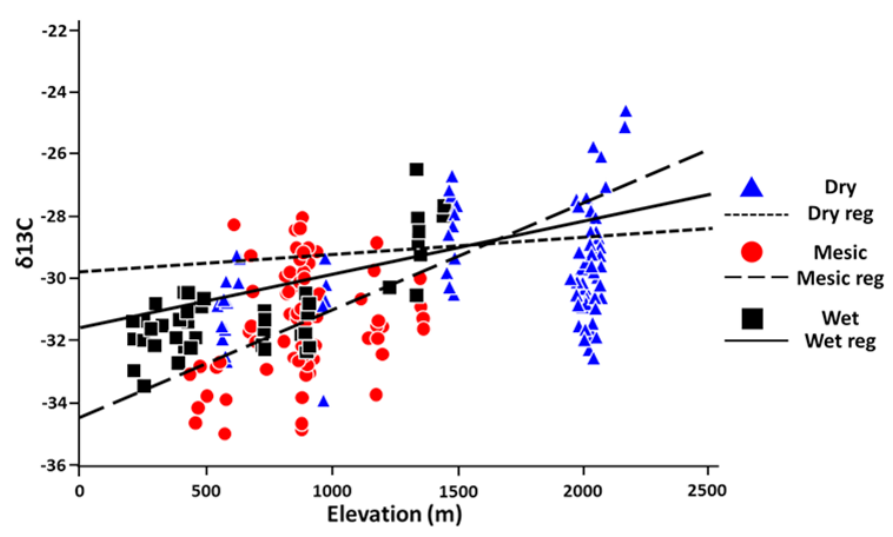

\section{Discussion}

This study sought to delineate variation in the isotopic signatures of Acacia koa across heterogeneous moisture and elevation gradients in Hawai'i. Global studies have found $\delta^{13} \mathrm{C}$ enrichment at high elevations in other regions, but other factors underlie these trends that can be difficult to disentangle. We were interested in defining whether stomatal conductance is a natural, reversible acclimation or a genetic adaptation that may signal population sub-structuring (Ward et al. 2005). In Hawai'i, high elevation sites are generally more xeric than low elevations and we were not able to sample trees on wet sites at high elevations. We would expect greater differentiation in mesic sites where stomatal conductance 
is not limited by xeric conditions. Trees at higher elevations exhibited both an expected greater $\delta^{13} \mathrm{C}$ ratio and water-use efficiency versus trees from low elevations, indicating that their stomata close more often than trees on dry sites at lower elevations. This work generates baseline data from which to investigate plasticity in koa using stable isotope and environmental variables to design future studies focusing on growth differences among koa stands across Hawai'i.

Our data related that heights in our primarily mesic regions were greater than those of primarily wet regions, with dry regions occupying an intermediate position. This trend may also be attributable to other factors associated with wet climates, such as wilt caused by the fungus Fusarium oxysporum, which is abundant in Hawaiian soils in high moisture low elevation areas. Interestingly, trees in wet sites had relatively high levels of fractionation at mid-elevations relative to dry sites. It is plausible that trees growing in wet sites are not as well adapted to xeric conditions. However, as we lack both seed source or genotype data, such adaptation responses can only be inferred.

Temperature and moisture also correlated with $\delta^{13} \mathrm{C}$ and followed expected trends, with high $\delta^{13} \mathrm{C}$ enrichment for low MAT, MAP, and MAE. These data indicated trees at higher elevations had lower stomatal conductance than trees from lower, warmer, and presumably wetter elevations. Exceptions to this trend were found during periods of drought or in drier regions of the tropics. As with Lins et al. (2016), we noted no consistent change in $\delta^{13} \mathrm{C}$ along elevational gradients examined in this work. The average $\delta^{13} \mathrm{C}$ for our data was $-29.8 \%$ and was similar to other investigations of tropical forest species (Vitousek et al. 1990, Duarte et al. 2005, Ometto et al. 2006, Maricle et al. 2011). Average $\delta^{13} \mathrm{C}$ for tropical species varies between $-26 \%$ and $-30 \%$ but these numbers are highly arbitrary as leaf age and light irradiance can have dramatic effects (Vitoria et al. 2016). Leaves exposed to great- er irradiances often have subsequently higher $\delta^{13} \mathrm{C}$ ratios. The $\delta^{13} \mathrm{C}$ ratios of younger leaves (-28.8 and -30.8) and mature leaves (-29.1 and -31.7) were further decreased with increased irradiance (Vitoria et al. 2016). Thus, leaf age is directly related to $\delta^{13} \mathrm{C}$ enrichment. It is possible some of the collected leaves were not of comparable age.

Temperature (MAT) is generally a primary factor influencing carbon isotope discrimination (Xu et al. 2015) but mineral nutrition may also have a strong effect on plant carbon isotope discrimination (Marshall \& Linder 2013). We observed a significant, strong correlation between $\delta^{15} \mathrm{~N}$ and $\delta^{13} \mathrm{C}\left(\mathrm{R}^{2}=0.30\right)$ which implied that low $\delta^{13} \mathrm{C}$ was associated with nitrogen acquired from decomposition as opposed to mineralization, where N2 is fixed through the atmosphere. Sites with higher MAP are more likely to have greater nitrogen uptake from decomposition, opposed to the costlier process of mineralization, as well as superior leaf production volumes. Hence, low elevation trees on mesic sites relied more on nitrification where $\delta^{15} \mathrm{~N}$ ratios were highly negative rather than N2-fixation where $\delta^{15} \mathrm{~N}$ values approach or exceed zero. Globally, increased soil $\mathrm{N}$ through decomposition is associated with increased foliar $\delta^{15} \mathrm{~N}$ (Craine et al. 2009). Dramatic effects of variations in precipitation and temperature on the mineralization of carbon and nitrogen have been reported previously for peat and bog soils (Keller et al. 2004) but not soils found in Hawai'i.

Climate change research studies have indicated that significant correlations exist between MAP and leaf $\delta^{15} \mathrm{~N}$ (Vitousek \& Austin 1998, Craine et al. 2009). As MAT increases, $\delta^{15} \mathrm{~N}$ increases worldwide (above $10{ }^{\circ} \mathrm{C}$ ), and as MAP increases, $\delta^{15} \mathrm{~N}$ decreases (Craine et al. 2009). Our study noted a negative correlation between MAP and MPY when compared to $\delta^{15} \mathrm{~N}\left(\mathrm{R}^{2}=0.2336\right.$ and $\left.\mathrm{R}^{2}=0.2053\right)$ but a very slight positive correlation between those climate variables and MPJ $\left(\mathrm{R}^{2}=0.1288\right)$. These variations may be attributed to extreme 
drought conditions at several sites, also referenced in a study by Werth et al., (2015), when looking at $\delta^{13} \mathrm{C}$ and $\delta^{15} \mathrm{~N}$ with respect to leaf age. Their work also mentioned oversaturated soils, like andosols found on some of our lowwet sites, can lead to soil $\delta^{15} \mathrm{~N}$ depletion and further affect foliar $\delta^{15} \mathrm{~N}$ accumulation (Deenik $\&$ McClellan 2007, Werth et al. 2015).

Research has suggested $\delta^{15} \mathrm{~N}$ values of tropical species should be greater than zero for undisturbed forests (Martinelli et al. 1999) however our data showed that many of our samples were below zero. These values indicated many of our sites were in disturbed forest habitats. Our samples from Hawai'i Volcanoes National Park (VNP) were separated out of the analysis to determine if the high sulfur and volatile gas content of vog (volcanic smog) would cause those data to be significantly different from samples collected at other sites. Our analyses indicated that the VNP sites were not statistically different from sites at similar elevation and precipitation levels (Supporting Information 3 ).

We were unable to gather soil isotope measurements, but recognize the influence that a leguminous tree species such as Acacia koa can have on the soil nutrient environment (Idol et al. 2007). Our sites were primarily histosols or andosols, the major soil types in Hawai' $i$ (Deenik \& McClellan 2007). Histosols are generally $50 \%$ organic matter and often drain rapidly leading to nitrogen leaching over time while andosols are around $25 \%$ organic matter. Some of the most fertile soils in Hawai'i occur in regions with lower precipitation $(<150$ cm) (Deenik \& McClellan 2007). Soils on Hawai'i are very young and likely have depleted nitrogen when compared to soils on the other islands. However, as climate changes have more of an effect, phosphorus may also become co-limited (Vitousek et al. 2004; Menge et al. 2012). Also, seasonal fluctuations of soil inorganic nitrogen in the tropics has been previously illustrated (Song et al. 2015). Nitrogen data in other legume and non-legume species indicated higher foliar nitrogen levels in le- gumes however, we did not observe elevated nitrogen levels in this study. The change in $\delta^{15} \mathrm{~N}$ across the gradient in our study supports previous work that surmised that koa fixes-N facultatively (Hedin et al. 2009).

Typically, nitrates accumulate slowly during the dry season and more quickly during the start of the rainy season (Supporting Information 4). As precipitation continues, nitrate levels begin to drop. This process is repeated when dry periods are interspersed between heavy rains. Previous research on tropical trees species by Ometto et al. (2006) reported no seasonal variation in $\delta^{15} \mathrm{~N}$ but did note dry season associated variations in $\delta^{13} \mathrm{C}$. Other researchers have shown that $\delta^{13} \mathrm{C}$ is positively correlated with MAP in non-leguminous species and negatively correlated in leguminous trees (Song et al. 2016), but those data explained only $19 \%$ of the variance in $\delta^{13} \mathrm{C}$. Here we noted a similar pattern however it was site-specific. Closer analysis of weather conditions revealed that mean annual precipitation (MAP) combined with mean annual temperature (MAT) may have influenced the presence of significant correlations. These data indicated that changes in precipitation and temperature may have influenced the $\% \mathrm{C}$ found in foliar samples during July but not during January. A likely reason is that these data were collected Hawai'i was amid a significant, several-years long drought that may have complicated data analyses.

Percent carbon levels in foliage were lower on dry sites than mesic or wet sites at either elevation examined. This may result from halted leaf growth in response to extreme drought or other, more subtle, environmental influences. Foliar $\% \mathrm{~N}$ levels were often lower in dry sites than wet sites except for the Mid-wet sites where $\% \mathrm{~N}$ was slightly lower than at the Middry sites. Thus, these results indicated that the invasive grasses that cover the higher elevation sites may have leached a surfeit amount of nitrogen from the available pool and left less for Acacia koa trees to accumulate. This could also explain why a great majority of those trees 
had negative nitrogen values. Higher mean values for $\delta^{13} \mathrm{C}$ were observed at the High-dry sites $(-27.9 \%$ ) and the lowest values were recorded at Low-mesic sites (-31.1\%). Foliar $\delta^{13} \mathrm{C}$ ratios were indicative of abiotic stress conditions during growth. We expected to see a clear pattern where the highest $\delta^{13} \mathrm{C}$ values were recorded at the lowest rainfall sites, the combination of drought and high temperatures may have increased evapotranspiration and humidity thus creating new moisture gradients capable of having influential effects (positive and negative) on isotope trends.

We considered species composition of various sites and compared results from a site that was primarily koa to one that consisted of several other species such as O'hia (Metrosideros polymorpha) and noted no significant differences for any parameters examined as sites composed exclusively of koa were not unlike those interspersed with O'hia. Although it is widely known that the richly organic excrement left after free-range cattle grazing can significantly influence later isotope readings, presence of cattle at or near some of the sites was sparse enough that no significant differences were observed in the resultant data when similar sites were compared. Early work by Giardina et al. (2003) noted fertilization with potassium could improve GPP in Sydney blue gum (Eucalyptus saligna) planted in Hawai'i and recent work by Nottingham et al. (2015) indicated phosphorus rather than $\mathrm{N}$ interfered with the ability of microbes to metabolize $\mathrm{C}$ in some tropical soils. Perhaps analyses that include both potassium and phosphorus would help future studies on the topic. It was initially thought that nitrogen-fixing koa could be planted alongside other native Hawaiian species to boost nitrogen availability however, evidence from a similar study by Riedel et al. (2013) with Rosy trumpet tree (Tabebuia rosea) and the nitrogen-fixer Gliricidia (Gliricidia sepium) showed no significant difference in nitrogen accumulation in non-leguminous species. Planting nitrogen-fixing Acacia trees in dryland areas would increase soil organic 290 carbon stocks (Abaker et al. 2016) and further revitalize the soil (Githae et al. 2013) however, care should be taken not to overzealously plant these trees in extremely unsuitable environments.

While we cannot hope to understand the plethora of interacting variables found across the sites of this island (i.e. volcanos, free-range cattle grazing, aggressively invasive grasses) that may have contributed to the isotope readings observed, these data accurately document the variability in stable isotopes across the many ecoregions of the island of Hawai'i. Sites in this work considered most suitable for the focus of future reforestation efforts were those with the greatest water-use efficiency and the most negative nitrogen isotope ratios. Sites were reevaluated and divided into three groups after taking these notes into consideration. Thus, following our results and logic, the best overall candidate sites for koa restoration were the Upper Waiakea Forest Reserve northwest of Flume Road (FLM), various sites within Volcanoes National Park (VNP-A, -B, $-\mathrm{C}$ ), and both sites off of Saddle Road (MIL, $\mathrm{SAD})$. The next best locations for koa restoration efforts were the Waiakea Forest Reserve southeast of Stainback Highway (SBR), the Ola'A Forest Reserve west of Volcano Road (VNP-E) and our final site within Volcanoes National Park (VNP-D). The final sites in our study (PHH, WAI, HON, MAU, and BIR) can all be used in restoration efforts however, our data indicated the greatest water-use and nitrogen-use efficiencies were found at those sites first listed. In addition, the Stainback Highway region is the current site of the state planned Waiakea commercial timber harvest where an estimated 16 million cubic feet of timber (primarily maple, ash, and Eucalyptus) is expected to be removed. This would make restoration efforts with koa in that area easier to initiate. More research is also needed into companion species, suitable for planting alongside Acacia $k o a$, that can both enhance growth and help alleviate abiotic stresses. Data shown here will be used in initial analyses of the suitabil- 
ity of each of these sites for later outplanting efforts. Because results presented herein were obtained over a short period, long-term observation may be necessary to determine if these trends in stable isotope ratios have continued.

\section{Conclusions}

The data from this study yielded results consistent with those seen in other tropical species however potential influences of abiotic stress during sampling cannot be overlooked. These data, therefore, suggested that successful reestablishment of Acacia koa trees is likely to vary because of prior land use and nutrient availability. Proper soil type, MAT, MAP, and ecological niche are vital to the reestablishment of koa on disturbed sites. Overall, our findings indicated that koa growing at higher elevations within the same moisture region showed decreased $\delta^{13} \mathrm{C}$ discrimination as elevation increased. With respect to $\delta^{15} \mathrm{~N}$, we noted that the hardier samples, those found at high dry elevations, also demonstrated the most negative $\delta^{15} \mathrm{~N}$ values.

To further examine climate change effects on Acacia koa at these sites, additional information regarding soil mineralization may be collected. It is necessary to compare data obtained during this drought period to those collected after conditions have returned to normal. This comparative analysis will help differentiate those variables influenced by the exceedingly abnormal temperature conditions. Future research efforts will also focus on comparative analysis of RNA expression data to determine which genes were differentially expressed across the various sites. It is believed that these expression data will help clarify which genes are up- or downregulated in high elevation koa thus, potentially responsible for allowing greater tolerance to suboptimal growth conditions.

Our finding that tree heights correlated positively with $\delta^{13} \mathrm{C}$ and that trees were consistently taller on mesic rather than wet or dry conditions is corroborated by other studies. Tanaka-Oda et al. (2010) reported decreased $\delta^{13} \mathrm{C}$ for Populus $x$ hopeiensis and black locust (Robinia pseudoacacia) and increased $\delta^{13} \mathrm{C}$ Siberian elm (Ulmus pumila) when compared to tree height, while Zheng \& Shang (2007) reported that decreased precipitation led to dramatic $(30 \%)$ increase in $\delta^{13} \mathrm{C}$ for tropical broadleaf species within the Loess Plateau of China.

Worthy of note, are newly published data that indicated accelerated rates of turnover in fungal and bacterial communities within the rhizosphere shuttle more carbon through fungal nutrient energy pathways than previously accredited bacterial pathways (Pausch et al. 2016). Thus, future studies of Acacia koa will likely involve thorough inspection of fungal contributions to nutrient pools, additional leaf ecophysiological traits and later foliar incorporation, as well as genetic evaluations. To ensure a genetically integrative test group, later projects may incorporate genotyping to ensure samples are as diverse as possible within the study regions.

\section{Acknowledgements}

The authors thank Drs. John Kabrick, John Stanovick, and Mark Coggeshall for their comments and critiques of a previous version of this manuscript. We also thank Matt Paschen, Orianna Rueda-Kraus, Sara Knox, and Holli Tidwell for help with sample collection and Dr. Faith Inman for help with collection of samples, precipitation, and temperature data. We acknowledge the State of Hawai'i Department of Land and Natural Resources (DLNR) - Division of Forestry and Wildlife (DOFAW) and/or State Parks, as well as the USDA Forest Service (FS) as land managers and administrators for the Hawai'i Experimental Tropical Forest. Funding provided by the US Forest Service and the Atherton Family Foundation. Mention of a trademark, proprietary product, or vendor does not constitute a guarantee or 
warranty of the product by the US Department of Agriculture and does not imply its approval to the exclusion of other products or vendors that also may be suitable.

\section{References}

Abaker WE., Berninger F., Saiz G., Braojos V., Starr M., 2016. Contribution of Acacia senegal to biomass and soil carbon in plantations of varying age in Sudan. Forest Ecology and Management 368:71. DOI: 10.1016/j. foreco.2016.03.003

Aitken SN., Yeaman S., Holliday JA., Wang T., Curtis-McLane S., 2008. Adaptation, migration or extirpation: climate change outcomes for tree populations. Evolutionary Applications 1:95-111. DOI: 10.1111/j.17524571.2007.00013.x

Ares A., Fownes JH., Sun W., 2000. Genetic differentiation of intrinsic water-use efficiency in the Hawaiian native Acacia koa. International Journal of Plant Sciences 161:909-915. DOI: 10.1086/317559

Becklin KM., Medeiros JS., Sale KR., Ward JK., 2014. Evolutionary history underlies plant physiological responses to global change since the last glacial maximum. Ecology Letters 17:691-699. DOI: 10.1111/ ele. 12271

Bell BA, Fletcher WJ., Ryan P., Grant H., Ilmen R., 2017. Stable carbon isotope analysis of Cedrus atlantica pollen as an indicator of moisture availability. Review of Paleobotany and Palynology 244:128-139. DOI: https:// doi.org/10.1016/j.revpalbo.2017.04.008

Berry ZC., Smith WK., 2012. Cloud pattern and water relations in Picea rubens and Abies fraseri, southern Appalachian Mountains, USA. Agricultural and Forest Meteorology 162-163:27-34. DOI: 10.1016/j.agrformet.2012.04.005

Berry ZC., White JC., Smith WK., 2014. Foliar uptake, carbon fluxes and water status are affected by the timing of daily fog in saplings from a threatened cloud forest. Tree Physiology 34:459-470. DOI: 10.1093/treephys/ tpu032

Bussotti F., Pollastrini M., 2015. Evaluation of leaf features in forest trees: Methods, techniques, obtainable information and limits. Ecological Indicators 52:219-230. DOI: 10.1016/j.ecolind.2014.12.010

Čada V., Šantrůčková H., Šantrůček J., Kubištová L., Seedre M., Svoboda M., 2016. Complex physiological response of Norway Spruce to atmospheric pollution - Decreased carbon isotope discrimination and unchanged tree biomass increment. Frontiers in Plant Science 7:805-813. DOI: 10.3389/fpls.2016.00805

Cai ZQ., Poorter L., Han Q., Bongers F., 2008. Effects of light and nutrients on seedlings of tropical Bauhinia lianas and trees. Tree Physiology 28:1277-1285. DOI: 10.1093/treephys/28.8.1277

Casper BB., Goldman R., Lkhagva A., Helliker BR., Plan292 te AF., Spence LA., Liancourt P., Boldgiv B., Petraitis PS., 2012. Legumes mitigate ecological consequences of a topographic gradient in a northern Mongolian steppe. Oecologia 169:85-94. DOI: 10.1007/s00442011-2183-x

Craine JM., Elmore AJ., Aidar MPM., Bustamante M., Dawson TE., Hobbie EA., Kahmen A., Mack MC., McLauchlan KK., Michelsen A., Nardoto GB., Pardo LH., Penuelas J., Reich PB., Schuur EAG., Stock WD., Templer PH., Virginia RA., Welker JM., Wright IJ., 2009. Global patterns of foliar nitrogen isotopes and their relationships with climate, mycorrhizal fungi, foliar nutrient concentrations, and nitrogen availability. New Phytologist 183:980-992. DOI: 10.1111/j.14698137.2009.02917.x

Craven D., Gulamhussein S., Berlyn GP., 2010. Physiological and anatomical responses of Acacia koa (Gray) seedlings to varying light and drought conditions. Environmental and Experimental Botany 69:205-213. DOI: 10.1016/j.envexpbot.2010.04.002

Deenik J., McClellan AT., 2007. Soils of Hawai'i. Soil and Crop Manage. Cooperative Extension Service University of Hawai'i, Manoa. Soil and Crop Management 20:1-12.

Duarte HM., Geßler A., Scarano FR., Franco AC., Mattos, EAD., Nahm M., Rennenberg H., Rodrigues PJFP., Zaluar HLT., Lüttge U., 2005. Ecophysiology of six selected shrub species in different plant communities at the periphery of the Atlantic forest of SE-Brazil. Flora 200:456-476. DOI: 10.1016/j.flora.2005.02.004

Farley KA., Bremer LL., Harden CP., Hartsig J., 2012. Changes in carbon storage under alternative land uses in biodiverse Andean grasslands: implications for payment for ecosystem services. Conservation Letters 6:21-27. DOI: 10.1111/j.1755-263X.2012.00267.x

Giardina CP., Ryan MG., Binkley D., Fownes JH., 2003. Primary production and carbon allocation in relation to nutrient supply in a tropical experimental forest. Global Change Biology 9:1438-1450. DOI: 10.1046/j.13652486.2003.00558.x

Githae EW., Gachene CKK., Njoka JT., Omondi SF., 2013. Nitrogen Fixation by Natural Populations of Acacia Senegal in the Drylands of Kenya Using 15 N Natural Abundance. Arid Land Research and Management 27:327-336. DOI: 10.1080/15324982.2013.784377

Gulías J., Cifre J., Jonasson S., Medrano H., Flexas J., 2009. Seasonal and inter-annual variations of gas exchange in thirteen woody species along a climatic gradient in the Mediterranean island of Mallorca. Flora 3:169-181. DOI: 10.1016/j.flora.2008.01.011

Hagan DL., Jose S., 2011. Interspecific competition enhances nitrogen fixation in an actinorhizal shrub. Plant Ecology 212:63-68. DOI: 10.1007/s11258-010-9803-0.

Hall SJ., Hale RL., Baker MA., Bowling DR., Ehleringer JR., 2015. Riparian plant isotopes reflect anthropogenic nitrogen perturbations: robust patterns across land use gradients. Scandinavian Journal of Forest Research 6:116. DOI: 10.1890/ES15-00319.1. 
Hansen D., Steig E., 2016. Comparison of water-use efficiency and internal leaf carbon dioxide concentration in juvenile leaves and phyllodes of Acacia koa (Leguminosae) from Hawai'i, estimated by two methods. American Journal of Botany 80:1121-1125. DOI: http://www. jstor.org/stable/2445539

Hietz P., 1998. Diversity and conservation of epiphytes in a changing environment. Pure and Applied Chemistry 70:23-27. DOI: http://fradnai.free.fr/docs/doc17.pdf

Idol T., Baker PJ., Meason D., 2007. Indicators of forest ecosystem productivity and nutrient status across precipitation and temperature gradients in Hawai'i. Journal of Tropical Ecology 23:693-704. DOI: 10.1017/ S0266467407004439

Juday GP., Alix C., Grant TA., 2015. Spatial coherence and change of opposite white spruce temperature sensitivities on floodplains in Alaska confirms early-stage boreal biome shift. Forest Ecology and Management 350:46-61. DOI: 10.1016/j.foreco.2015.04.016

Keller J., White J., Bridgham S., Pastor J., 2004. Climate change effects on carbon and nitrogen mineralization in peatlands through changes in soil quality. Global Change Biology 10:1053-1064. DOI: 10.1111/j.13652486.2004.00785.x

Kohn MJ., Thiemens MH., 2010. Carbon isotope compositions of terrestrial C3 plants as indicators of (paleo) ecology and (paleo)climate. Proceedings of the National Academy of Sciences USA 107:19691-19695. DOI: 10.1073/pnas. 1004933107

Kolivras KN., Comrie AC., 2007. Regionalization and variability of precipitation in Hawai'i. Physical Geography 28:76-96.

Krushelnycky PD., 2014. Evaluating the Interacting influences of pollination, seed predation, invasive species and isolation on reproductive success in a threatened alpine plant. Public Library of Science (PLOS) One. 9:e88948. DOI: 10.1371/journal.pone.0088948

Krushelnycky PD., Loope LL., Giambelluca TW., Starr F., Starr K., Drake DR., Taylor AD., Robichaux RH., 2013. Climate-associated population declines reverse recovery and threaten future of an iconic high-elevation plant. Global Change Biology 19:911-922. DOI: 10.1111/gcb.12111

Liancourt P., Spence LA., Song DS., Lkhagva A., Sharkhuu A., Boldgiv B., Helliker BR., Petraitis PS., Casper BB., 2013. Plant response to climate change varies with topography, interactions with neighbors, and ecotype. Ecology 94:444-453. DOI: 10.1890/12-0780.1

Lins SRM., Coletta LD., de Campos-Ravagnani E., Gragnani JG., Mazzi EA., Martinelli LA., 2016. Stable carbon composition of vegetation and soils across an altitudinal range in the coastal Atlantic Forest of Brazil. Trees 30:1315-1329. DOI: 10.1007/s00468-016-1368-7

Liu J., Yunhong T., Slik JWF., 2014. Topography related habitat associations of tree species traits, composition and diversity in a Chinese tropical forest. Forest Ecology and Management 330:75-81. DOI: 10.1016/j.foreco.2014.06.045
Lynott MJ., Boutton TW., Price JE., Nelson DE., Antiquity SA., Jan N., 1986. Society for American Archaeology: Stable carbon isotopic evidence for maize agriculture in Southeast Missouri and Northeast Arkansas. American Antiquity 51:51-65. DOI: 10.2307/280393

Magdas DA., Cristea G., Puscas R., Tusa F., 2014. The use of isotope ratios in commercial fruit juices authentication. Romanian Journal of Physics 59:355-359

Marcott S., Shakun JD., Clark PU., Mix AC., 2013. A reconstruction of regional and global temperature for the past 11,300 years. Science 339:1198-1201. DOI: 10.1126/science. 1228026

Marshall JD., Linder S., 2013. Mineral nutrition and elevated [CO2] interact to modify $13 \mathrm{C}$, an index of gas exchange, in Norway spruce. Tree Physiology 33:11321144. DOI: 10.1093/treephys/tpt004

Martinelli LA., Piccolo MC., Townsend AR., Vitousek PM., Cuevas E., McDowell W., Robertson GP., Santos OC., Treseder K., 1999. Nitrogen stable isotopic composition of leaves and soil: Tropical versus temperate forests. Biogeochemistry 46:45-65. DOI: 10.1023/A:1006100128782

Menge DNL., Hedin LO., Pacala SW., 2012. Nitrogen and phosphorus limitation over long-term ecosystem development in terrestrial ecosystems. Public Library of Science (PLOS) One. 7:e42045. DOI: 10.1371/journal. pone.0042045.

Mihailova A., Pedentchouk N., Kelly SD., 2014. Stable isotope analysis of plant-derived nitrate - Novel method for discrimination between organically and conventionally grown vegetables. Food Chemistry 154:238-245. DOI: 10.1016/j.foodchem.2014.01.020

Murakami H., Wang B., Li T., Kitoh A., 2013. Projected increase in tropical cyclones near Hawai'i. Nature Climate Change. 3:749-754. DOI: 10.1038/nclimate 1890

Nottingham AT., Turner BL., Stott AW., Tanner EVJ., 2015. Nitrogen and phosphorus constrain labile and stable carbon turnover in lowland tropical forest soils. Soil Biology and Biochemistry 80:26-33. DOI: 10.1016/j. soilbio.2014.09.012

Ometto JPHB., Ehleringer JR., Domingues TF., Berry JA., Ishida FY., Mazzi E., Higuchi N., Flanagan LB., Nardoto GB., Martinelli LA., 2006. The stable carbon and nitrogen isotopic composition of vegetation in tropical forests of the Amazon Basin, Brazil. Biogeochemistry 79:251-274. DOI: 10.1007/s10533-006-9008-8.

Ozolincius R., Lekevicius E., Stakenas V., Galvonaite A., Samas A., Valiukas D., 2014. Lithuanian forests and climate change: possible effects on tree species composition. European Journal of Forest Research 133:51-60. DOI: $10.1007 / \mathrm{s} 10342-013-0735-9$

Pausch J., Kramer S., Scharroba A., Scheunemann N., Butenschoen O., Kandeler E., Marhan D., Riederer M., Scheu S., Kuzyakov Y., Ruess L., 2016. Small but active - pool size does not matter for carbon incorporation in below-ground food webs. Functional Ecology 30:479-489. DOI: 10.1111/1365-2435.12512

Perakis SS., Tepley AJ., Compton JE., 2015. Disturbance 
and Topography Shape Nitrogen Availability and $\delta 15 \mathrm{~N}$ over Long-Term Forest Succession. Ecosystems 18:573-588. DOI: 10.1007/s10021-015-9847-z

Peri PL., Ladd B., Pepper DA., Bonser SP., Laffan SW., Amelung W., 2012. Carbon $(\delta 13 \mathrm{C})$ and nitrogen $(\delta 15 \mathrm{~N})$ stable isotope composition in plant and soil in Southern Patagonia's native forests. Global Change Biology 18:311-321. DOI: 10.1111/j.1365-2486.2011.02494.x

Peterson BJ., Fry B., 1987. Stable isotopes in ecosystems studies. Annual Review of Ecology and Systematics 18:293-320. DOI: 10.1146/annurev. es.18.110187.001453

Rannow S., 2013. Do shifting forest limits in south-west Norway keep up with climate change? Do shifting forest limits in south-west Norway keep up with climate change? Scandinavian Journal of Forest Research 28:574-580. DOI: 10.1080/02827581.2013.793776

Riedel J., Dorn S., Plath M., Mody K., 2013. Growth, herbivore distribution, and herbivore damage of timber trees in a tropical silvopastoral reforestation system. Annals of Forest Science 70:75-86. DOI: 10.1007/ s13595-012-0239-7

Robinson D., 2001. $\delta 15 \mathrm{~N}$ as an integrator of the nitrogen. Trends in Ecology and Evolution 16:153-162. DOI: 10.1016/s0169-5347(00)02098-x

Roggy JC., Prévost MF., Gourbiere F., Casabianca H., Garbaye J., Domenach AM., 1999. Leaf natural $\delta 15 \mathrm{~N}$ abundance and total $\mathrm{N}$ concentration as potential indicators of plant $\mathrm{N}$ nutrition in legumes and pioneer species in a rain forest of French Guiana. Oecologia 120:171-182. DOI: $10.1007 / \mathrm{s} 004420050846$

Safeeq M., Mair A., Fares A., 2013. Temporal and spatial trends in air temperature on the Island of Oahu, Hawai'i. International Journal of Climatology 33:28162835. DOI: $10.1002 /$ joc.3629

Scholl MA., Gingerich SB., Tribble GW., 2002. The influence of microclimates and fog on stable isotope signatures used in interpretation of regional hydrology: East Maui, Hawaii. Journal of Hydrology 264:170-184. DOI: 10.1016/S0022-1694(02)00073-2

Schulze ED., Ellis R., Schulze W., Trimborn P., Ziegler H., 1996. Diversity, metabolic types and $\delta 13 \mathrm{C}$ carbon isotope ratios in the grass flora of Namibia in relation to growth form, precipitation and habitat conditions. Oecologia 106:352-369. DOI: 10.1007/BF00334563

Schulze ED., Williams RJ., Farquhar GD., Schulze W., Langridge J., Miller JM., Walker BH., 1998. Carbon and nitrogen isotope discrimination and nitrogen nutrition of trees along a rainfall gradient in northern Australia. Australian Journal of Plant Physiology 25:413-425. DOI: $10.1071 /$ PP97113

Song M., Djagbletey G., Nkrumah EE., Huang M., 2015. Patterns in leaf traits of leguminous and non-leguminous dominant trees along a rainfall gradient in Ghana. Journal of Plant Ecology 9:69-76. DOI: 10.1093/jpe/ rtv038

Soolanayakanahally RY., Guy RD., Street NR., Robinson KM., Silim SN., Albrectsen BR., Jansson S., 2015.
Comparative physiology of allopatric Populus species: geographic clines in photosynthesis, height growth, and carbon isotope discrimination in common gardens. Frontiers in Plant Science 6:1-11. DOI: 10.3389/ fpls.2015.00528 Stevenson BA., Kelly EF., McDonald EV., Busacca AJ., 2005. The stable carbon isotope composition of soil organic carbon and pedogenic carbonates along a bioclimatic gradient in the Palouse region, Washington State, USA. Geoderma 124:37-47. DOI: 10.1016/j.geoderma.2004.03.006

Vitasse Y., Delzon S., Bresson CC., Michalet R., Kremer A., 2009. Altitudinal differentiation in growth and phenology among populations of temperate-zone tree species growing in a common garden. Canadian Journal of Forest Research 39:1259-1269. DOI: 10.1139/X09-054 Vitasse Y., Lenz A., Kollas C., Randin CF., Hoch G., Körner C., 2014. Genetic vs. non-genetic responses of leaf morphology and growth to elevation in temperate tree species. Functional Ecology 28:243-252. DOI: 10.1111/1365-2435.12161

Vitoria AP, Viera TD, Camargo PD, Santiago LS., 2016. Using leaf $\mathrm{d} 13 \mathrm{C}$ and photosynthetic parameters to understand acclimation to irradiance and leaf age effects during tropical forest regeneration. Forest Ecology and Management 379:50-60. DOI: 10.1016/j.foreco.2016.07.048

Vitousek PM., 1998.The structure and functioning of montane tropical forests: control by climate, soils, and disturbance. Ecology. 79:1-2. DOI: 10.1890/0012-9658

Vitousek PM., Ladefoged TN., Kirch PV., Hartshorn AS., Graves MW., Hotchkiss SC., Tulajapurkar S., Chadwick OA., 2004. Soils, Agriculture, and Society in Precontact Hawai'i. Science 304:1665-1669. DOI: 10.1126/science. 1099619

Vitousek PM., Turner DR., Parton WJ., Sanford RL., Sanford RL., 1994. Litter Decomposition on the Mauna Loa Environmental Matrix, Hawai'i: Patterns, Mechanisms, and Models. Ecology 75:418-429. DOI: http:// www.jstor.org/stable/1939545

Vlam M., Baker PJ., Bunyavejchewin S., Zuidema PA., 2014. Temperature and rainfall strongly drive temporal growth variation in Asian tropical forest trees. Oecologia 174:1449-1461. DOI: 10.1007/s00442-013-2846-X Voelker SL., Brooks JR., Meinzer FC., Anderson R., Bader MKF., Battipaglia G., Becklin KM., Beerling D., Bert D., Betancourt JL., Dawson TE., Domec JC., Guyette RP., Korner C., Leavitt SW., Linder S., Marshall JD., Mildner M., Ogee J., Panyushkina I., Plumpton HJ., Pregitzer KS., Saurer M., Smith AR., Siegwolf RTW., Stambaugh MC., Talhelm AF., Tardif JC., Van de Water PK., Ward JK., Wingate L., 2016. A dynamic leaf gas-exchange strategy is conserved in woody plants under changing ambient $\mathrm{CO} 2$ : Evidence from carbon isotope discrimination in paleo and $\mathrm{CO} 2$ enrichment studies. Global Change Biology 22:889-902. DOI: 10.1111/gcb.13102

Ward M., Dick CW., Gribel R., Lowe AJ., 2005. To self, or not to self ... A review of outcrossing and pollen-me- 
diated gene flow in neotropical trees. Heredity 95:248254. DOI: $10.1038 /$ sj.hdy. 6800712

Watzka M., Buchgraber K., Wanek W., 2006. Natural 15N abundance of plants and soils under different management practices in a montane grassland. Soil Biology and Biochemistry 38:1564-1576. DOI: http://dx.doi. org/10.1016/j.soilbio.2005.11.007

Werth M., Mehltreter K., Briones O., Kazda M., 2015. Stable carbon and nitrogen isotope compositions change with leaf age in two mangrove ferns. Flora 210:80-86. DOI: 10.1016/j.flora.2014.11.001

Xu M., Wang G., Li X., Cai X., Li X., Christie P., Zhang J., 2015. The key factor limiting plant growth in cold and humid alpine areas also plays a dominant role in plant carbon isotope discrimination. Frontiers in Plant Science 6:961-969. DOI: 10.3389/fpls.2015.00961

Zheng S., Shangguan Z., 2007. Spatial patterns of foliar stable carbon isotope compositions of $\mathrm{C} 3$ plant species in the Loess Plateau of China. Ecological Research 22:342-353. DOI: 10.1007/s11284-006-0024-x

Zhu Y., Siegwolf RTW., Durka W., Körner C., 2010. Phylogenetically balanced evidence for structural and carbon isotope responses in plants along elevational gradients. Oecologia 162:853-863. DOI: 10.1007/ s00442-009-1515-6

\section{Supporting Information}

The online version of the article includes Supporting Information:

Supporting Information 1. USGS data of the recorded drought conditions in the years before, during, and after the study

Supporting Information 2. Frequency histograms comparing isotope data when samples from Volcanoes National Park (VNP) are excluded.

Supporting Information 3. Mean annual precipitation and temperature across the sites for January and July combined with stable isotope data.

Supporting Information 4. Origins, site descriptions, locations, and elevations of sampled Acacia koa trees. 